\title{
The Thirteenth Amendment and Access to Education for Children of Undocumented Workers: A New Look at Plyler v. Doe
}

\author{
By Maria L. Ontiveros* \& Joshua R. Drexler**
}

\section{I} N THE LATE SUMMER OF 2007, public school officials in North Chicago turned away Latino school children seeking to register for the fall. ${ }^{1}$ The officials refused to enroll the students because their parents did not provide proof of legal residency or work authorization. ${ }^{2}$ After intervention by the Mexican American Legal Defense and Education Fund ("MALDEF"), the school district reversed its decision and allowed the children to register. ${ }^{3}$ Although the Chicago school district's action violated established law, other school districts have taken similar actions, and some states have attempted to pass legislation to

* Maria L. Ontiveros, Professor of Law, University of San Francisco School of Law. This article was developed from a working paper prepared for the roundtable, "The Education of All Our Children: The 25th Anniversary of Plyler v. Doe," sponsored by the Chief Justice Earl Warren Institute on Race, Ethnicity \& Diversity (University of California, Berkeley, Boalt Hall School of Law), held on May 7, 2007. Thanks are due to all participants in the roundtable (including Maria Blanco, Jorge Chapa, Maria Echaveste, Patricia Gandara, Lucas Guttentag, Goodwin Liu, Rachel Moran, Hiroshi Motomura, Michael Olivas, Robert Rubin, Leticia Saucedo, and John Trasvina) for their helpful exchange of ideas and especially to Aarti Kohli for administering the roundtable. I appreciate the excellent research assistance of Sun Kim, J.D. U.S.F. 2008, and the insights provided by my colleagues Connie de la Vega and James Pope, as well as those of my coauthor, Joshua P. Drexler. It is dedicated to all immigrant children and their parents who aspire to a better life through education.

** Joshua R. Drexler, J.D. Candidate, May 2008, University of San Francisco School of Law; B.S., Colorado State University, 2001. I would like to thank my wife for her unfailing support and Professor Ontiveros for the honor of this collaboration, as well as her guidance through ethical dilemmas and constitutional conundrums.

1. Bill Howe, MALDEF Protects the Constitutional Rights of Students to Enroll in Public Schools, http://nameorg.org/pipermail/name-mce_nameorg.org/2007-August/ 002463.html (Aug. 17, 2007, 4:45 EST).

2. Id.

3. Id. 
the same effect. ${ }^{4}$ These actions target the estimated 1.8 million undocumented children in this country ${ }^{5}$ and seek to undo the $1982 \mathrm{Su}$ preme Court case, Plyler $v$. Doe, ${ }^{6}$ which established the right of undocumented children to attend public school.

Plyler examined the issue of the rights of undocumented children to attend public school under the Fourteenth Amendment. ${ }^{7}$ While reaffirming the Fourteenth Amendment analysis, this Article offers an alternative way to analyze the issue. It examines the extent to which the Thirteenth Amendment can be used to guarantee access to public education for the children of undocumented workers. It argues that the Thirteenth Amendment can provide a powerful tool for litigation, moral persuasion, and organizing in support of these children. Viewing access to education for children of undocumented workers through a Thirteenth Amendment lens reveals an important way in which this group of workers could suffer a situation that replicates the evils society sought to prohibit with the Thirteenth Amendment.

The Thirteenth Amendment states, "Neither slavery nor involuntary servitude . . shall exist in the United States." As a growing number of courts and authors have recognized, the Thirteenth Amendment does more than prohibit chattel slavery as practiced in the South prior to the Civil War..$^{9}$ According to the Amendment's legislative history, social understanding, and legal doctrine, it also prohibits restrictive labor arrangements that replicate the harms of slavery-the "badges and incidents" of slavery. ${ }^{10}$ Examining how the Thirteenth Amendment applies to modern day situations provides the opportunity for society and the judiciary to realize these original aspirations. ${ }^{11}$

4. See infra Part I.

5. Jeffrey S. Passel, Pew Hispanic Ctr., Size and Characteristics of the Unauthorized Migrant Population in the U.S.: Estimates Based on the March 2005 Current Population Survey (2007) (estimating that according to the 2005 census, 1.8 million undocumented children resided in the United States).

6. 457 U.S. 202 (1982)

7. Id. at 205.

8. U.S. CONST. amend. XIII, $\S 1$. The second section of the amendment authorizes Congress to enact legislation pursuant to this mandate. $I d . \S 2$.

9. See infra Part III.

10. See Maria L. Ontiveros, Noncitizen Immigrant Labor and the Thirteenth Amendment: Challenging Guest Worker Programs, 38 U. ToL. L. REv. 923, 924 (2007).

11. Analysis of the legislative history which supports this expansive reading of the Thirteenth Amendment can be found in James Gray Pope, Labor's Constitution of Freedom, 106 Yale L.J. 941 (1997); Benjamin P. Quest, Comment, Process Theory and Emerging Thirteenth Amendment Jurisprudence: The Case of Agricultural Guest Workers, 41 U.S.F. L. Rev. 233 
This Article rests on the theory that the institutionalized treatment of undocumented immigrant workers ${ }^{12}$ in the United States has become suspect under the Thirteenth Amendment. The presence and treatment of undocumented workers in this country has become this century's "peculiar institution." 13 They are a caste of workers of color, laboring beneath the floor for free labor, denied the rights of citizenship, and subject to human rights abuses. ${ }^{14}$ Like slavery in the early nineteenth century, the fact that the United States has a stated policy against undocumented immigration and purportedly wants the undocumented immigrants gone does not eliminate the facts that they are here, that the state has set up a variety of structures that facilitate their subordination, and that certain segments of society benefit from their presence. In fact, this institution has been established through a series of immigration and economic policies which encourage the presence of this exploitable caste of workers. Like slavery after the Civil War, the Constitution provides a legal framework for dismantling that institution. To the extent that denial of education to the children of undocumented workers becomes part-and-parcel of this peculiar institution, the Thirteenth Amendment should prohibit it.

Part I of this Article discusses the current legal and social situation of undocumented students and their access to public education. It focuses on the Fourteenth Amendment analysis of the issue, as developed in Plyler, and it also discusses the subsequent interpretations, challenges, and affirmations of Plyler. Part II examines an alternative legal approach to the issue, and it presents a re-imagined version of Plyler. The re-imagined opinion incorporates both the original language of the opinion, as well as additional language based on Thirteenth Amendment jurisprudence that supports the outcome. Part III examines the Thirteenth Amendment justification in more detail. It presents a brief synopsis of Thirteenth Amendment jurisprudence in general and as applied to educational rights for undocumented children. This Part also looks to avenues beyond litigation for using the

(2006); Lea S. Vandervelde, The Labor Vision of the Thirteenth Amendment, 138 U. PA. L. Rev. 437 (1989).

12. Other articles have argued that the institutionalized treatment of legal immigrant workers, on certain types of visas, also runs afoul of the Thirteenth Amendment. See Ontiveros, supra note 10. This Article focuses exclusively on the treatment of undocumented workers.

13. The phrase "peculiar institution" refers to the system of slavery in the southern states of the United States. The New Oxford American Dictionary (Erin McKean ed., 2d ed. 2005) available at Oxford Reference Online.

14. Maria L. Ontiveros, Immigrant Workers' Rights in a Post-Hoffman World-Organizing Around the Thirteenth Amendment, 18 GEO. IMMIGR. L.J. 651, 654-55 (2004). 
Thirteenth Amendment to guarantee the educational rights of undocumented children by focusing upon its use as a moral call and an organizational tool.

\section{The Current Legal and Social Landscape Regarding Undocumented Children and Access to Public Education}

\section{A. Plyler v. Doe}

In September of 1977, schools in Smith County, Texas told children of Mexican origin they had two options if they wanted to join their classmates at school that year: they had to provide legal documentation of their right to reside in the United States or pay $\$ 1000 .{ }^{15}$ Laura Alvarez and her siblings did not have the documents required by Smith County, and the Alvarez family did not have the economic means to pay for education, so the children could no longer attend school. ${ }^{16}$ The Alvarez children were not alone in their predicament, so they brought suit in federal court along with three other families. ${ }^{17}$ Five years later, in the landmark case of Plyler v. Doe, the United States Supreme Court struck down the Texas statute which had authorized Texas schools to exclude undocumented children and prohibited any state funding to be spent on the education of undocumented children. ${ }^{18}$ The Court found the statute unconstitutional under the Equal Protection Clause of the Fourteenth Amendment. ${ }^{19}$

Under traditional Fourteenth Amendment jurisprudence, state action is subject to "strict scrutiny" by the courts when the state action targets a "suspect class" (such as a racial group) or affects a "fundamental right" (such as the right to marry) ${ }^{20}$ State actions in this category must be narrowly tailored to serve a compelling state interest in order to be upheld. ${ }^{21}$ Most other state actions, those not targeting a suspect class or affecting a fundamental right, need only pass "rational basis" scrutiny-the action just needs to be rationally related to a legitimate state interest to pass constitutional muster under the Four-

15. Barbara Belejack, A Lesson in Equal Protection, Tex. Observer, July 13, 2007, http:/ /www.texasobserver.org/article.php?aid=2548.

16. Id.

17. Id.

18. Plyler v. Doe, 457 U.S. 202, 230 (1982).

19. Id.

20. See McLaughlin v. Florida, 379 U.S. 184, 192 (1964).

21. Id. 
teenth Amendment. ${ }^{22}$ The Court has also carved out a narrow intermediate category to evaluate state actions "based on sex or illegitimacy" which receive a "heightened" standard of scrutiny, somewhere between strict scrutiny and rational basis. ${ }^{23}$

Justice Brennan's majority opinion in Plyler appears to place state action depriving undocumented children access to public schools in this intermediate category. ${ }^{24} \mathrm{He}$ justified this intermediate level of scrutiny by casting education as a type of quasi-fundamental right, stating that education is not "merely some governmental benefit indistinguishable from other forms of social welfare legislation." ${ }^{25} \mathrm{He}$ went on to say that "it is doubtful that any child may reasonably be expected to succeed in life if he is denied the opportunity of an education." 26 Further, the class of plaintiffs deserved unique protection for two reasons. First, the children were part of a "caste of undocumented resident aliens, encouraged by some to remain here as a source of cheap labor, but nevertheless denied the benefits that our society makes available to citizens and lawful residents." ${ }^{27}$ Second, the children were being singled out and punished not for their own actions, but for the actions of their parents. ${ }^{28}$ For all these reasons, the Court used intermediate scrutiny.

Applying the intermediate standard, Justice Brennan declared that the State had not demonstrated that the Texas law would further the State's purported goals of relieving economic burdens on the State, improving "the overall quality of education in the State," or ensuring Texas resources benefit Texas rather than some other locality. ${ }^{29}$ The Court's conclusion that the record did not support such a finding has lead to vigorous research and debate on the educational and societal costs and benefits of Plyler over the past twenty-five years. ${ }^{30}$

The heightened level of Fourteenth Amendment analysis used in Plyler has been criticized because undocumented immigrants do not

22. Plyler, 457 U.S. at $216-17$.

23. Kadrmas v. Dickinson Pub. Sch., 487 U.S. 450, 459 (1988).

24. Plyler, 457 U.S. at 217-18 (requiring Texas to show a "substantial interest"), 218 n.16 (characterizing the analysis as "intermediate scrutiny").

25. Id. at 221 .

26. Id. at 223 (quoting Brown v. Bd. of Educ., 347 U.S. 483, 493 (1954)).

27. Id. at $218-19$.

28. Id. at 220 .

29. Id. at 229 .

30. Nina Rabin et al., Understanding Plyler's Legacy: Voices from Border Schools, 37 J.L. \& Educ. 15, 17 (2008) (presenting "a more complex accounting of Plyler's effects than usually characterizes the public debate over its costs and benefits"). 
fit neatly into the category of a "suspect class" and because the Supreme Court has held that the right to education is not necessarily a fundamental right. ${ }^{31}$ Critics argue, as Justice Burger stated in his dissent, "[B]y patching together bits and pieces of what might be termed quasi-suspect-class and quasi-fundamental-rights analysis, the Court spins out a theory custom-tailored to the facts of these cases." $32 \mathrm{Al}$ though the opinion has withstood attack and been reaffirmed, ${ }^{33}$ this potential weakness concerns advocates of educational rights for undocumented children.

\section{B. An Overview of the Situation Since Plyler}

\section{The Social Landscape: Two Million Reasons Why Plyler Is Still Important}

Upholding Plyler remains vitally important. Plyler is as relevant today as it was in 1982 when the Supreme Court held that Texas could not deny education to its undocumented children, including the more than 10,000 children living in the Houston area who were at the heart of Plyler. ${ }^{34}$ At the time of the opinion, over 400,000 undocumented residents in the United States were under the age of eighteen. ${ }^{35}$ Today that number approaches two million. ${ }^{36}$ These children are part of a total undocumented population in the United States numbering more than eleven million. ${ }^{37}$

The children impacted by Plyler today vary significantly from their counterparts in 1982. Approximately twelve percent live with siblings who are citizens. ${ }^{38}$ A little more than half immigrated to the United

31. San Antonio Indep. Sch. Dist. v. Rodriguez, 411 U.S. 1, 28-29 (1973).

32. Plyler, 457 U.S. at 244 (Burger, J., dissenting).

33. Papasan v. Allain, 478 U.S. 265, 285-87 (1986). This Article does not suggest that Plyler v. Doe was decided incorrectly. It is the firm belief of the authors that the decision, as currently written, is correct. This section merely seeks to suggest areas that are subject to attack and to suggest an alternative way to arrive at the same correct outcome.

34. Estevan T. Flores, Research on Undocumented Immigrants and Public Policy: A Study of the Texas School Case, 18 Int'L Migration Rev. (Special Issue) 505, 506, 517 (1984).

35. Jeffrey S. Passel \& Karen A. Woodrow, Geographic Distribution of Undocumented Immigrants: Estimates of Undocumented Aliens Counted in the 1980 Census by State, 18 InT'L MigraTION Rev. (SPECIAL Issue) 642, 662 (1984).

36. Passel, supra note 5 (estimating that according to the 2005 census, 1.8 million undocumented children resided in the United States).

37. Id.

38. Jefrrey S. Passel, Pew Hispanic Citr., Unauthorized Migrants: Numbers and Characteristics, Background Briefing Prepared for Task Force on Immigration and AMERICA's Future 20 (2005). 
States from Mexico. ${ }^{39}$ Although the most undocumented children probably reside in California, ${ }^{40}$ there are signs that states in the South have seen the largest increases in recent years. ${ }^{41}$ Somewhat surprisingly, some scholars estimate that a higher percentage of undocumented students graduate from high school than do minority students who are citizens. ${ }^{42}$ These undocumented children include some of the best and the brightest our nation has to offer. ${ }^{43}$ Regardless of how this nation chooses to treat these children, it will continue to benefit from their presence.

\section{The Legal Landscape: A Fundamental Right to Minimally Adequate, But Not Necessarily Equal, Education}

In Brown v. Board of Education, ${ }^{44}$ the Supreme Court stated that access to education, "where the state has undertaken to provide it, is a right which must be made available to all on equal terms." ${ }^{45}$ The Court would later construe Brown's promise of equal education much more narrowly than was initially hoped for by minority communities. Despite the setbacks to equal education, Supreme Court cases since Brown do continue to suggest that a fundamental right to a minimally adequate education does exist, and that a total deprivation of access would violate constitutional norms.

Perhaps the biggest blow to Brown's vision of equal education came in San Antonio Independent School District v. Rodriguez, ${ }^{46}$ where the Supreme Court upheld a Texas school finance system which created gross disparities between schools located in wealthy neighborhoods

39. PASSEL, supra note 5 (estimating that fifty-seven percent of all undocumented residents originate from Mexico).

40. See Fortuny et al., Urban Inst., The Characteristics of Unauthorized Immigrants in California, Los Angeles County, and The United States vi (2007).

41. Pew Hispanic Ctr., The New Latino South: The Context and Consequences of Rapid Population Growth 4 (2005), available at http://pewhispanic.org/reports/report. php? ReportID $=50$ (showing the largest increases in the Latino population in southern states). North Carolina, for example, experienced almost a $400 \%$ increase in its Latino population during the 1990s. Id.

42. Orfield et al., Civil Rights Project at Harvard Univ. \& Urban Inst., Losing Our Future: How Minority Youth Are Being Left Behind by the Graduation Rate Crisis (2004).

43. Four undocumented students from Hayden High School in Phoenix won an esteemed national robotics competition. Soon after their success they were arrested while crossing the Canadian border on a class trip. Peter Carlson, Stinky the Robot, Four Kids and a Brief Whiff of Success, WASH. PosT, Mar. 29, 2005, at C1.

44. 347 U.S. 483 (1954).

45. Id. at 493 .

46. 411 U.S. 1 (1973). 
and those in poor minority neighborhoods. ${ }^{47}$ Because fifty percent of a school's resources were collected from local property taxes, the ten school districts with the lowest minority populations received more than double the funding per child than the districts which were home to the highest minority populations. ${ }^{48}$ The Court declared that strict scrutiny of the Texas finance system was unnecessary because it did not target a suspect class, and a right to equal educational opportunites is not a fundamental right. ${ }^{49}$

Despite the result reached in Rodriguez, the Court did leave a small opening for future progress. The Court emphasized that it was not presented with a factual situation involving a school system that failed "to provide each child with an opportunity to acquire the basic minimal skills necessary for the enjoyment of the rights of speech and of full participation in the political process." 50 Rather, the opinion only addressed a system involving "relative differences in spending levels" between school districts. ${ }^{51}$ The Court widened that very opening with its decision in Plyler. Later, the Court declared that Rodriguez and Plyler have not "definitively settled the questions whether a minimally adequate education is a fundamental right and whether a statute alleged to discriminatorily infringe that right should be accorded heightened equal protection review." 52

In 1988, the Court again refused to foreclose a fundamental rights analysis for access to a basic education when it decided Kadrmas v. Dickenson Public Schools. ${ }^{53}$ In that case the Court held that North Dakota schools could require rural residents to pay eleven percent of the transportation costs for their children. ${ }^{54}$ Further, pursuant to this decision, the Dickenson Public Schools could deny transportation to Sarita Kadrmas when her parents would not pay the transportation fee. ${ }^{55}$ Although the holding again encroached on the right to equal educational opportunities, as the dissent pointed out, the majority opinion stressed "that the denial of transportation to Sarita Kadrmas did not in fact prevent her from receiving an education" because

47. Id. at $54-55$.

48. See id. at 15 n. 38 .

49. Id. at $28-29$.

50. Id. at 37 .

51. Id.

52. Papasan v. Allain, 478 U.S. 265, 285 (1986) (refusing to resolve the issue of whether a fundamental right exists and remanding to resolve whether the unequal distribution of funding was constitutional under a rational basis theory).

53. 487 U.S. 450 (1988).

54. Id. at $454-56$.

55. Id. at 454 . 
Sarita's family was able to secure transportation for her. ${ }^{56}$ Justice Marshall's dissent went on to state, "[T]he Court therefore does not address the question whether a State constitutionally could deny a child access to a minimally adequate education." 57

As the Supreme Court noted in Plyler, its jurisprudence has a long history of finding that education holds a unique place among state services. ${ }^{58}$ Although Rodriguez demonstrates that the Court is not willing to declare equal education a fundamental right, it may be willing to find that "some degree of education is necessary to prepare citizens to participate effectively and intelligently in our open political system if we are to preserve freedom and independence." 59 As such, the Court should find that a fundamental right exists if confronted with a situation involving a total deprivation of education.

\section{The Legislative Landscape: Skirmishes at the Federal, State, and Local Levels}

Despite the Supreme Court's rulings, hard work remains for those who wish to secure educational access for all children in the United States. As one commentator put it, the real fight has come in enforcing Plyler locally. ${ }^{60}$ Numerous incursions on educational rights, both legislatively and administratively, have required advocates to defend the progress made by Plyler.

\section{a. Federal Legislation}

In 1996, the so-called "Gallegly Amendment" sought to permit "states to deny public education benefits to certain aliens not lawfully present in the United States." 61 The amendment failed in part due to a congressional compromise, in part due to President Clinton's veto threat, and in part due to opposition emanating from unlikely sources, such as the two Texas Republican senators at the time. ${ }^{62}$ Indeed this indicates Texas has made progress since Plyler, with consid-

56. Id. at 466 (Marshall, J., dissenting).

57. Id. at 466 n.1.

58. Plyler v. Doe, 457 U.S. 202, 221 (1982).

59. Wisconsin v. Yoder, 406 U.S. 205, 221 (1972).

60. Many of the developments noted in this section were discovered through an insightful article written by Professor Michael Olivas. For a more in-depth look, see Michael A. Olivas, Immigration Related State and Local Ordinances: Preemption, Prejudice, and the Proper Role for Enforcement, 2007 U. CHI. Legal F. 27, 36-45.

61. H.R. 4134, 104th Cong. (1996).

62. Philip G. Schrac, A Well-Founded Fear: The Congressional Battlee to Save Political Asylum in America 185, 245, 311 n.33 (2000). 
erable educational programs aimed at improving the experience of migrant children in the Texas school system. ${ }^{63}$

A federal statute enacted in 1996 prohibits foreign parents from sending their children to the United States to live with relatives or sponsors in order to obtain education for the children. ${ }^{64}$ Providing some insight into issues that might arise under the statute, in 1997 an Illinois court interpreted a similar state statute to find that a school could not refuse to accept a document notarized by a judge in Mexico granting custodial rights to a child's aunt in Illinois. ${ }^{65}$

\section{b. State Legislation}

One of the most famous state level attempts to restrict the rights of undocumented immigrants occurred in 1994, when fifty-nine percent of California's voters passed Proposition 18766 ("Prop 187"). The referendum affected life for undocumented residents at nearly every conceivable point of contact with the California government. ${ }^{67} \mathrm{~A}$ key provision banned undocumented children from public education. ${ }^{68} \mathrm{~A}$ federal judge found almost all aspects of Prop 187 unconstitutional based on either Plyler or preemption grounds. ${ }^{69}$ After appealing the case, the litigants settled the matter before the Ninth Circuit could rule on the substantive matters of the claim. ${ }^{70}$

In the first half of 2006, more than 500 immigration-related bills were introduced in state legislatures. Forty-four of the bills were enacted in nineteen states. ${ }^{71}$ Although not all of the bills were restrictive in nature, some were drastically so. ${ }^{72}$ While these types of state bills are not new, the flurry of activity does give some cause for alarm.

63. Olivas, supra note 60 , at $40-41$.

64. 8 U.S.C. $\$ 1184(\mathrm{~m})(2000)$.

65. Joel R. v. Bd. of Educ., 686 N.E.2d 650 (Ill. App. Ct. 1997).

66. See Bill Jones, Cal. Sec'y of State, Statement of the Vote: November 8, 1994 General Election, at 111 (Nov. 8, 1994) (reporting that California voters approved Proposition 187 by a fifty-nine to forty-one percent margin).

67. See Lolita K. Buckner Innis, Califormia's Proposition 187-Does It Mean What It Says? Does It Say What It Means? A Textual and Constitutional Analysis, 10 Geo. IMmiGr. L.J. 577 (1996).

68. California Ballot Pamphlet: General Election November 8, 1994, at 92 (Nov. 8 1994) (adding Cal Educ. Code $\$ 48215$ (a)).

69. League of United Latin Am. Citizens v. Wilson, 997 F. Supp. 1244 (C.D. Cal. 1997).

70. Patrick J. McDonnell, Davis Won't Appeal Prop. 187 Ruling, Ending Court Battles, L.A. Times, July 29, 1999, at A1.

71. Olivas, supra note 60 , at 31 .

72. See id. at 32 n.15. 


\section{c. Local Level Activity}

Since schools are administering the law at the local level, their policies and procedures can indirectly affect access to education. Michael Olivas points out that attorneys for MALDEF "have had to file several dozen actions since the early 1980s to enforce Plyler's clear holding, including combating school board actions requiring Social Security numbers [and] school requests for driver's licenses to identify parents . . . designed to identify immigration status or single out undocumented children." 73 Virginia recently recognized the dangers associated with requiring the use of social security numbers and passed legislation forbidding such use. ${ }^{74}$

Some local challenges to Plyler have been more direct. In the Illinois school system, a school board refused admission to a student on the ground that her family's B-2 tourist visa expired. ${ }^{75}$ The Elmwood Park School Board, however, revised its policy after the state's board of education threatened to withhold funding. ${ }^{76}$ As discussed in the introduction to this Article, in 2007 a school district in northern Chicago also attempted to turn away children based on similar grounds.

Other challenges have taken on a brutal tone. In 1992, INS authorities harassed students suspected of being undocumented at Bowie High School, near the border in El Paso. ${ }^{77}$ The Border Patrol made their presence known by "driving over the football practice field and baseball diamond, entering the football locker rooms, surveilling with binoculars from the football stadium, and using binoculars to watch flag girls practicing on campus." ${ }^{78}$ Authorities routinely subjected the students to "indecent comments, obscene gestures, and humiliation in the presence of their . . friends, family, and relevant community."79 The aggression reached a high point when some students, along with a school coach, were detained at gunpoint. ${ }^{80}$

73. Id. at 39 .

74. 2003 Va. Acts 637 (amending Section 22.1-260 of the Code of Virginia).

75. Rosalind Rossi, State Strips Schools of $\$ 3.5$ million: District Following Law, It Claims, by Refusing to Enroll Immigrant, CHI. Sun-Times, Feb. 24, 2006, at News-8.

76. Eric Herman, Elmwood Park Schools Reinstated: District Agrees to Stop Barring Siudents Due to Immigration Status, CH. Sun-Times, Feb. 25, 2006, at A3; Colleen Mastony \& Diane Redo, Elmwood Park Schools Give In; To Kecp State Funds, District Drops Fight on Immigrant Student, CHI. TRIB., Feb. 25, 2006, at News-1.

77. Murillo v. Musegades, 809 F. Supp. 487, 490-96 (W.D. Tex. 1992).

78. Id. at 495 .

79. Id. at 501 .

80. Id. at 491 
In 2004, administrators at a school in northern New Mexico turned three of its own students over to the Border Patrol when it found the students just beyond school grounds. ${ }^{81}$ The students filed a complaint in federal court claiming that the school, the Albuquerque Police Department, and Border Patrol violated the students' constitutional rights, including the right to attend public school. ${ }^{22}$ The students agreed to a settlement requiring the district to stop the illegal practices, educate its personnel regarding the rights of immigrant students, and create a liaison for immigrant parents. ${ }^{83}$

In 2006, "mixed evidence" arose showing Immigration and Customs ("ICE") agents came onto school grounds in Austin, Texas to apprehend the children of parents arrested on suspicion of being in the country illegally. ${ }^{84}$ Similar reports surfaced the following year in Austin, ${ }^{85}$ as well as in Santa Fe, New Mexico. ${ }^{86}$ Recent evidence from 2008 suggests that ICE could be stepping up its antagonism of the undocumented population. ${ }^{87}$ In California, an exemplary student and immigrant rights activist at Palomar College was arrested and deported, along with her mother and father. ${ }^{88}$

On the other hand, many local communities appreciate and support the ideas found in Plyler. ${ }^{89}$ One recent survey of school personnel in six Arizona public schools found that the vast majority of personnel with an opinion on the issue supported the law established by Plyler and believed "a law prohibiting undocumented students from attending public schools would have a negative $(36 \%)$ or very negative $(35 \%)$ impact on the relationship between their school and the community."90

81. Amy Miller, APS Safe for Migrant Students, AlbuQ. J., June 2, 2006, at A1.

82. Amy Miller, Migrants Are Safe at APS, AlbuQ. J., June 15, 2006, at C1.

83. Id.

84. Texas Civil Rights Project Newsclip, Email Warns of Illegal Immigration Crackdowns in Classrooms (Apr. 26, 2006), http://www.texascivilrightsproject.org/newspub/ clip_060426_email_warns.html.

85. Katie Humphrey, Parents Without ID Denied Access to Del Valle Schools, New Policy Protects Students, District Says, Austin Am.-Statesman, Apr. 8, 2007, at B1.

86. Raam Wong, ICE Picks up Dad at School, AlbuQ. J., Mar. 29, 2007, at A1; Raam Wong, State Police Apologize to School; ICE Agents Arrested Chaparral Student's Dad, ALBuQ. J., Apr. 7, 2007, at A1.

87. ICE Arrests MEChA President and Her Family, LA Voz de AztLan, Jan. 17, 2008, http:/ /www.aztlan.net/mecha_president_arrested.htm.

88. Id.

89. See Rabin et al., supra note 30 , at 42.

90. Id. 


\section{Plyler v. Doe Re-imagined}

Plyler and its progeny address the issue of providing education to undocumented children as a Fourteenth Amendment equal protection issue. This section presents an alternate version of key sections of the Plyler opinion, based on the Thirteenth Amendment. The alternative version includes both language from the existing opinion, as well as additional language based on Thirteenth Amendment doctrine. The new language is italicized. All citations found in the original opinion have been omitted. The re-imagined opinion addresses the two potential problems with the current opinion described above: the need for a "suspect class" and the need to identify a "fundamental right" for equal protection analysis.

The re-imagined opinion also addresses a third problem with $\mathrm{Ply}$ $l e r$ as currently written: its reaffirmation of the so-called plenary powers doctrine. Under this doctrine, the Supreme Court refuses to review congressional action in the area of immigration. ${ }^{91}$ In order for a Thirteenth Amendment challenge to a federal immigration policy penalizing undocumented workers or their children to prevail, the plenary powers doctrine must be overturned. ${ }^{92}$

\section{Plyler v. Doe, 457 U.S. 202 (1982) Re-imagined (2008)}

The question presented by these cases is whether, consistent with the Thirteenth Amendment, Texas may deny to undocumented schoolage children the free public education that it provides to children who are citizens of the United States or legally admitted aliens.

\section{I}

Since the late 19th century, the United States has restricted immigration into this country. Unsanctioned entry into the United States is a crime, and those who have entered unlawfully are subject to deportation. But despite the existence of these legal restrictions, a substantial number of persons have succeeded in unlawfully entering the United States, and now live within various States, including the State of Texas.

91. See Gabriel J. Chin, Segregation's Last Stronghold: Race Discrimination and the Constitutional Law of Immigration, 46 UCLA L. REv. 1 (1998).

92. Immigration scholars have insistenty called for a reversal of this policy. Id. at 7-8. Some courts have made incursions into the doctrine. See, e.g., Miller v. Christopher, 96 F.3d 1467, 1470-71 (D.C. Cir. 1996), affd, 523 U.S. 420 (1998); Giusto v. INS, 9 F.3d 8, 9-10 (2d Cir. 1993) (per curiam); Garcia v. INS, 7 F.3d 1320, 1327 (7th Cir. 1993); Campos v. INS, 961 F.2d 309, 316 (1st Cir. 1992). 


\section{A (457 U.S. 218)}

Sheer incapability or lax enforcement of the laws barring entry into this country, coupled with the failure to establish an effective bar to the employment of undocumented aliens, has resulted in the creation of a substantial "shadow population" of illegal migrants-numbering in the millions-within our borders. This situation raises the specter of a permanent caste of undocumented resident aliens, encouraged by some to remain here as a source of cheap labor, but nevertheless denied the benefits that our society makes available to citizens and lawful residents. The existence of such an underclass presents most difficult problems for a Nation that prides itself on adherence to principles of equality under law. The Thirteenth Amendment to the Constitution regulates the treatment of such a caste of workers.

Although often mistakenly assumed to be solely a ban on chattel slavery, our decisions make clear that it reaches a much broader array of labor arrangements and societal deprivations. As we stated in one of our first cases applying the Thirteenth Amendment,

Undoubtedly while negro slavery alone was in the mind of the Congress which proposed the thirteenth article, it forbids any other kind of slavery, now or hereafter. If Mexican peonage or the Chinese coolie labor system shall develop slavery of the Mexican or Chinese race within our territory, this amendment may safely be trusted to make it void. And so if other rights are assailed by the States which properly and necessarily fall within the protection of these articles, that protection will apply, though the party interested may not be of African descent. ... [I]t is necessary to look to the purpose which we have said was the pervading spirit of them all, the evil which they were designed to remedy, and the process of continued addition to the Constitution, until that purpose was supposed to be accomplished, as far as constitutional law can accomplish it.

The Slaughter-House Cases, 83 U.S. (36 Wall.), at 72 (1873).

In the twentieth century, we framed the issue broadly, "The plain intention [of the amendment] was to abolish slavery of whatever name and form and all its badges and incidents; to render impossible any state of bondage; to make labor free, by prohibiting that control by which the personal service of one man is disposed of or coerced for another's benefit, which is the essence of involuntary servitude."

Bailey v. Alabama, 219 U.S. 219, 241 (1910).

The treatment of undocumented workers is suspect under the Thirteenth Amendment because, like the labor arrangements discussed in these cases, their peculiar situation leaves them without the ability to protect themselves in the workplace. If they file claims for workplace treatment that falls below the statu- 
tory floor set for free labor, they are subject to deportation and/or ineligible for monetary remedies. Hoffman Plastic Compounds, Inc. v. NLRB, 535 U.S. 137 (2002). In addition, like those subject to chattel slavery, debt peonage, and vassalage, they are a group of workers of color who lack the social citizenship rights necessary to improve their stature in the United States. Amici briefs have documented the human rights abuses to which they are often subjected. Sarah Cleveland et al., Inter-American Court of Human Rights Amicus Curiae Brief: The United States Violates International Law When Labor Law Remedies are Restricted Based on Workers' Migrant Status, 1 Seattle J. Soc. Just. 795 (2003).

The Thirteenth Amendment can and must tackle a broad range of race, labor, and social issues when societal factors combine to create a caste of individuals (workers and their families) whose treatment replicates the harms which the Thirteenth Amendment was designed to eliminate. Such is the situation of undocumented workers and their families today. Any state or private action which furthers the subordination of this caste of workers properly falls within the ambit of the Thirteenth Amendment.

\section{U.S. 221}

Public education is not a "right" granted to individuals by the Constitution. But neither is it merely some governmental "benefit" indistinguishable from other forms of social welfare legislation. Both the importance of education in maintaining our basic institutions, and the lasting impact of its deprivation on the life of the child mark the distinction. The "American people have always regarded education and [the] acquisition of knowledge as matters of supreme importance." We have recognized "the public schools as a most vital civic institution for the preservation of a democratic system of government," and as the primary vehicle for transmitting "the values on which our society rests." "[A]s . . pointed out early in our history ... some degree of education is necessary to prepare citizens to participate effectively and intelligently in our open political system if we are to preserve freedom and independence." In addition, education provides the basic tools by which individuals might lead economically productive lives to the benefit of us all. In sum, education has a fundamental role in maintaining the fabric of our society. In fact, its denial was integral to the institution of slavery and the perpetuation of subordination of blacks following the Civil War. We cannot ignore the significant costs borne by our Nation when select groups are denied the means to absorb the values and skills upon which our social order rests.

In addition to the pivotal role of education in sustaining our political and cultural heritage, denial of education to some isolated 
group of children poses an affront to one of the goals of the Thirteenth Amendment: the abolition of a caste or population unable to reap the rewards of their own labor and succeed in society. Paradoxically, by depriving the children of any disfavored group of an education, we foreclose the means by which that group might raise the level of esteem in which it is held by the majority. But more directly, "education prepares individuals to be self-reliant and self-sufficient participants in society." Illiteracy is an enduring disability. The inability to read and write will handicap the individual deprived of a basic education each and every day of his life. The inestimable toll of that deprivation on the social, economic, intellectual and psychological well-being of the individual, and the obstacle it poses to individual achievement, make it most difficult to reconcile the cost or the principle of a status-based denial of basic education with the framework of equality embodied in the Thirteenth Amendment. What we said 28 years ago in Brown v. Board Of Education still holds true:

Today education is perhaps the most important function of state and local governments. Compulsory school attendance laws and the great expenditures for education both demonstrate our recognition of the importance of education to our democratic society. It is required in the performance of our most basic public responsibilities, even service in the armed forces. It is the very foundation of good citizenship. Today it is a principal instrument in awakening the child to cultural values, in preparing him for later professional training, and in helping him to adjust normally to his environment. In these days, it is doubtful that any child may reasonably be expected to succeed in life if he is denied the opportunity of an education. Such an opportunity, where the state has undertaken to provide it, is a right which must be made available to all on equal terms.

B

These well-settled principles allow us to determine the unconstitutionality of excluding undocumented children from public schools under the Thirteenth Amendment. As we found in Jones v. Mayer, 392 U.S. 409 (1968), the Amendment prohibits not only the institutions of slavery and involuntary servitude, but also the "badges and incidents" of slavery. The denial of education to slaves and their children was seen as necessary to the proper functioning of the institution of slavery. Following emancipation, the continued denial of education to blacks was an integral part of the structures that perpetuated the subordination of newly freed blacks and the generations which followed them. Although public education is not a fundamental right, the denial of such education to the children of undocumented workers is a "badge or incident" of slavery properly prohibited by the Thirteenth Amendment. 


\section{IV}

It is the State's principal argument, and apparently the view of the dissenting Justices, that the undocumented status of these children vel non establishes a sufficient rational basis for denying them benefits that a State might choose to afford other residents . . .

\section{U.S. 239}

The Constitution grants Congress the power to "establish an uniform Rule of Naturalization." Drawing upon this power, upon its plenary authority with respect to foreign relations and international commerce, and upon the inherent power of a sovereign to close its borders, Congress has developed a complex scheme governing admission to our Nation and status within our borders. The obvious need for delicate policy judgments has counseled the Judicial Branch to avoid intrusion into this field. However, congressional power in the area of immigration must not remain unfettered. To the extent that the plenary powers doctrine has been read to foreclose judicial review of congressional authority in matters relating to immigration, that policy is overstated. This conclusion is particularly true in situations where the policy on immigration runs afoul of other constitutional requirements and protections, such as those found in the Thirteenth Amendment. Further, traditional caution does not persuade us that unusual deference must be shown any state regulation on the education of undocumented children. The States enjoy no power with respect to the classifications of aliens.

\section{A Thirteenth Amendment Right to Public Education for Undocumented Children}

The first clause of the Thirteenth Amendment states, "Neither slavery nor involuntary servitude, except as a punishment for crime whereof the party shall have been duly convicted, shall exist in the United States ...."93 The second clause authorizes Congress to enact legislation to carry out this mandate. ${ }^{94}$ Two different ways to "read" the Thirteenth Amendment and its jurisprudence have emerged over time. The first "conservative," or literal, approach focuses on the two prongs of the Amendment's first section: the "slavery" prong and the "involuntary servitude" prong. The second "holistic" approach focuses on the intent of the first section as a whole. Both approaches provide

93. U.S. ConsT. amend. XIII, \$1.

94. Much of the modern day Thirteenth Amendment case law, discussed below, examines whether Congress has authority under the second clause to pass legislation. The situation described in this Article is different because it examines whether the Amendment's first clause could be used to strike down state action. 
support for the re-imagined Plyler opinion. In addition, the two approaches complement each other by providing alternative justifications for either a litigation strategy or a moral persuasion and organizing strategy in support of education for undocumented children. This section begins with a brief summary of these two approaches and then applies them to the issue of educational access for children of undocumented workers.

\section{A. A Brief Summary of Thirteenth Amendment Jurisprudence}

\section{The Conservative or Literal Approach: The Supreme Court's Two-Pronged Approach to the Thirteenth Amendment}

The language of the first section of the Thirteenth Amendment prohibits "slavery" and "involuntary servitude." 95 Under the conservative approach, a court examines the two prongs of the Amendment independently of one another. ${ }^{96}$ One way to organize the Supreme Court jurisprudence in this area is to divide the cases into those evaluating whether a challenged practice constitutes involuntary servitude and those prohibiting slavery.

The cases falling into the involuntary servitude line examine whether a worker suffers employer or state "coercion" which prevents him or her from terminating an employment relationship. ${ }^{97}$ The decisions from the early to mid part of the twentieth century struck down cases of debt peonage and similar arrangements. ${ }^{98}$ More recently, workers' rights advocates have successfully lobbied for legislation, based on the Thirteenth Amendment, to overturn a Supreme Court case that limited the type of coercion constituting involuntary servitude to physical coercion. ${ }^{99}$ The legislation has been used to bring a variety of cases involving trafficked workers in the United States. ${ }^{100}$

95. U.S. Const. amend. XIII, § 1.

96. Ontiveros, supra note 10 , at 924 .

97. See Pollock v. Williams, 322 U.S. 4 (1944); United States v. Reynolds, 235 U.S. 133 (1914); Bailey v. Alabama, 219 U.S. 219 (1910).

98. See Pollock, 322 U.S. at 4; Reynolds, 235 U.S. at 133; Bailey, 219 U.S. at 219.

99. Trafficking Victims Protection Act of 2000 (TVPA), 22 U.S.C. $\$$ 7101-10 (2000) (overturning United States v. Kozminski, 487 U.S. 931 (1988)).

100. See, e.g., Maria L. Ontiveros, Female Immigrant Workers and the Law: Limits and Opportunities, in The Sex of Class: Women Transforming American Labor 235, 245-48 (Dorothy Sue Cobble ed., 2007); Kathleen Kim, Psychological Coercion in the Context of Modern-Day Involuntary Labor: Revisiting United States v. Kozminski and Understanding Human Trafficking, 38 U. TOL. L. REv. 941 (2007); Kathleen Kim \& Kusia Hreshchyshyn, Human Trafficking Private Right of Action: Civil Rights for Trafficked Persons in the United States, 16 Hastings WoMEN's L.J. 1 (2004). 
The cases falling into the slavery line draw on very old Supreme Court language. Shortly after the passage of the Thirteenth Amendment, the Court stated that the Amendment decreed "civil and political freedom throughout the United States" and abolished not just slavery, but all "badges and incidents of slavery." 101 This language lay dormant for almost one hundred years. In 1968, in Jones v. Mayer, ${ }^{102}$ the Supreme Court used the Thirteenth Amendment to uphold a prohibition on private discrimination in real estate sales. ${ }^{103}$ It found that prohibitions on the ability to own land were part-and-parcel of slavery, and that continuing discrimination in the ability to own land contributed to continuing racial subordination. ${ }^{104}$

The Supreme Court extended this finding in a number of other cases. ${ }^{105}$ In Griffin v. Breckenridge, ${ }^{106}$ the Court upheld the so-called Ku Klux Klan Act, which protected the right to interstate travel from racially-motivated attacks. ${ }^{107}$ In Johnson v. Railway Express Agency, ${ }^{108}$ the Court upheld a prohibition on racial discrimination in the formation of employment contracts under the Thirteenth Amendment. ${ }^{109} \mathrm{Fi}$ nally, in Runyon v. McCrary, ${ }^{110}$ the Supreme Court prohibited private schools from discriminating on the basis of race, holding that such discrimination was prohibited as a badge and incident of slavery and constituted discrimination in the formation of contracts. In each of these cases, the Supreme Court upheld legislation passed by Congress pursuant to the slavery prong of the Thirteenth Amendment.

101. The Civil Rights Cases, 109 U.S. 3, 20 (1883).

102. 392 U.S. 409 (1968).

103. Id. at 439. The Court reached a similar conclusion in Tillman $v$. Wheaton-Haven Recreation Ass'n, Inc., 410 U.S. 431 (1973). Jones and its progeny drew on the groundbreaking scholarship of Jacobus tenBroek, Thirteenth Amendment to the Constitution of the United States: Consummation to Abolition and Key to the Fourteenth Amendment, 39 CAL. L. REV. 171 (1951).

104. Jones, 392 U.S. at 441-43.

105. Commentators have argued to extend these cases in a variety of other ways. See Akhil Reed Amar \& Daniel Widawsky, Child Abuse as Slavery: A Thirteenth Amendment Response to DeShaney, 105 HaRv. L. Rev. 1359, 1384-85 (1992); Joyce E. McConnell, Beyond Metaphor: Battered Women, Involuntary Servitude and the Thirteenth Amendment, 4 YALE J.L. \& FEMINISM 207, 239-43 (1991); Vanessa B.M. Vergara, Abusive Mail-Order Bride Marriage and the Thirteenth Amendment, 94 Nw. U. L. REv. 1547, 1569-71 (2000).

106. 403 U.S. 88 (1971).

107. Id. at 96 .

108. 421 U.S. 454 (1975).

109. Id. at 459-60.

110. 427 U.S. 160 (1976). 


\section{Beyond the Two-Pronged Approach: The Holistic Approach}

The second way to read the Thirteenth Amendment focuses on a holistic approach, rather than a two-pronged approach. ${ }^{111}$ A holistic approach to the Thirteenth Amendment argues that analyzing the slavery and involuntary servitude prongs independently of one another presents too narrow a reading of the history and social understanding of the Thirteenth Amendment. The holistic approach examines the Amendment in its entirety and argues that the Amendment prohibits arrangements that interfere with workers' rights, citizenship rights, human rights, and civil rights, even outside the context of slavery. Understood through its history, case law, and social meaning, the Thirteenth Amendment did more than free and protect the rights of slaves. It also sought to protect workers by providing a floor for free labor, under which no worker may struggle. ${ }^{112}$ In addition, it sought to guarantee certain social citizenship rights. These social citizenship rights, separate from paper citizenship and naturalization rights, are similar to those rights denied freed blacks and sometimes described as the badges and incidents of slavery in the slavery prong cases of the conservative approach. ${ }^{113}$ Last, but certainly not least, the Amendment sought to protect society by ensuring the prohibition of certain kinds of evils, which we often view today as human or civil rights violations. ${ }^{114}$

The various commentators who use the conservative approach to analyze the Thirteenth Amendment are not wrong in their interpretations; however, commentators can enrich Thirteenth Amendment jurisprudence by examining situations where all of the strands of the Amendment come together. In addition, the holistic approach may present the best avenue for reintroducing the concept of the Thirteenth Amendment as a moral framework for addressing the treatment of undocumented workers. Finally, this holistic approach may be the best way to support the cases, like the re-imagined Plyler, which involve action by the courts striking down state action under the Thir-

111. This argument has been developed in Ontiveros, supra note 14, at $662-70$ and was expanded in Ontiveros, supra note 10, at 925.

112. See James Gray Pope, Labor's Constitution of Freedom, 106 YALE L.J. 941, 944 (1997); Lea S. VanderVelde, The Labor Vision of the Thirteenth Amendment, 138 U. PA. L. REv. 437, 443 (1989).

113. Ontiveros, supra note 10 , at 924-25.

114. See generally Risa L. Goluboff, The Thirteenth Amendment and the Lost Origins of Civil Rights, 50 DukE L.J. 1609 (2001), for a discussion of the use of the Thirteenth Amendment to justify the African American civil rights agenda. 
teenth Amendment, rather than cases which uphold congressional authority to pass legislation.

\section{B. Analyzing the Denial of Education Using the Conservative Approach to the Thirteenth Amendment}

\section{Frameworks for Applying the Conservative Approach}

Within the conservative approach to the Thirteenth Amendment, two authors have put forward frameworks to evaluate whether certain deprivations run afoul of the slavery prong's prohibition on badges and incidents of slavery. ${ }^{115}$ William Carter looks at: (1) the connection between the class to which the plaintiff belongs and the institution of chattel slavery and (2) the connection between the complained-of injury to the institution of slavery. ${ }^{116} \mathrm{He}$ argues that if the plaintiff is not African American, or some other historical victim of class-based discrimination, it is more difficult (but not impossible) to establish a Thirteenth Amendment claim. ${ }^{117}$ Other groups can establish claims when the types of injuries or forms of discrimination practiced are closely tied to the structures supporting or created by the system of slavery. ${ }^{118}$

Alex Tsesis, on the other hand, focuses on the freedom and liberty guaranteed by the Amendment's prohibition on slavery. He argues that the Amendment contains a negative prohibition against social and economic injustices that abridge fundamental liberties, ${ }^{119}$ including, but not limited to, the rights to make parental decisions, to travel, and to enter into employment and real estate contracts, as well as a positive grant of freedom. ${ }^{120} \mathrm{He}$ emphasizes that the Amendment's protection should not "stop at the disabilities existing contemporaneously with the passage of the amendment and the federal laws

115. The involuntary servitude prong of the conservative approach is not implicated in either of the frameworks.

116. William M. Carter, Jr., Race, Rights, and the Thirteenth Amendment: Defining the Badges and Incidents of Slavery, 40 U.C. Davis L. REv. 1311, 1318 (2007) [hereinafter Carter, Jr., Race, Rights, and the Thirteenth Amendment]; see also William M. Carter, Jr., Judicial Review of Thirteenth Amendment Legislation: "Congruence and Proportionality" or "Necessary and Proper"? 38 U. Tol. L. Rev. 973 (2007) [hereinafter Carter, Jr., Judicial Review of Thirteenth Amendment Legislation].

117. See generally Carter, Jr., Race, Rights, and the Thirteenth Amendment, supra note 116; Carter, Jr., Judicial Review of Thirteenth Amendment Legislation, supra note 116.

118. See generally Carter, Jr., Race, Rights, and the Thirteenth Amendment, supra note 116; Carter, Jr., Judicial Review of Thirteenth Amendment Legislation, supra note 116.

119. Alex Tsesis, The Thirteenth Amendment and American Freedom: A Legal HisTORY 89 (2004).

120. Id. at 96-97. 
that followed on its bootstraps. The broader question is whether there continue to be indicia of servitude that interfere with the lives, liberties, and well-being of persons within the United States ...."121 Under the Tsesis approach, the Thirteenth Amendment prohibits such interferences.

\section{The Conservative Thirteenth Amendment Frameworks Applied to the Denial of Education}

Carter and Tsesis provide conservative approaches to defining conduct prohibited under the Thirteenth Amendment because their analyses accept the Supreme Court's two-pronged approach to Thirteenth Amendment analysis and focus squarely on the slavery prong. In addition, their analyses track, to some extent, Fourteenth Amendment analysis by looking at something akin to protected classes and fundamental rights (Carter) or a constitutional guarantee of liberty (Tsesis). Since these analyses track existing doctrine and may be most acceptable to the Judiciary, their approaches might be the best starting point in any litigation dealing with education for undocumented school children.

The denial of education to children of undocumented workers fits within either scholar's framework. Under the Carter approach, undocumented workers and their children are very much like the class of people harmed by chattel slavery. They are non-citizen workers of color, laboring beneath the floor for free labor ${ }^{122}$ and subjected to violations of human, civil, and workplace rights. ${ }^{123}$ As the Plyler opinion noted, the confluence of government policies has resulted in

the existence of a large number of employed illegal aliens, such as the parents of plaintiffs in this case, whose presence is tolerated, whose employment is perhaps even welcomed, but who are virtually defenseless against any abuse, exploitation, or callous neglect to which the state or the state's natural citizens and business organizations may wish to subject them. ${ }^{124}$

All the Plyler opinions note the life-long nature of the caste to which uneducated undocumented children would be confined. ${ }^{125}$

121. Id. at 96 .

122. They labor beneath the floor for free labor because they lack access to the workplace protections guaranteed to free workers. Ontiveros, supra note 14, at 673-74.

123. See id.

124. Plyler v. Doe, 457 U.S. 202, 219 n.18.

125. Id. at 219, 230 (Marshall, J., concurring); 234 (Blackmun, J., concurring); 239 (Powell, J., concurring). 
Both the Carter and Tsesis approaches would look to the role denial of education played in the institution of chattel slavery, the perpetuation of racial subordination, and its impact on the freedom of individuals. Denial of education was key to the institution of slavery, and many states prohibited slaves from receiving any form of education. ${ }^{126}$ The systematic exclusion of blacks from education following the Civil War perpetuated racial subordination. Henry Allen Bullock shows how, following the Civil War, "the South, in keeping with its traditional prejudices, hurriedly erected barriers against the realization of two of the Negro's most pressing aspirations: the aim to become a full-fledged citizen and the desire to educate his children."127 Some states, such as North Carolina, closed black schools and made it a crime to teach blacks how to read. ${ }^{128}$ Other states, such as Florida, imposed special taxes on blacks to maintain black schools. ${ }^{129}$ Most blacks could not afford the taxes, and the inadequate funding led to inadequate schools. Social pressures also impeded black children from receiving education. ${ }^{130}$

James Anderson describes the dominant type of education offered to blacks as a unique form of second-class education to reinforce the social oppression of black southerners. ${ }^{131}$ The Hampton Normal and Agricultural Institute, for example, was founded "to socialize blacks to understand and accept their disenfranchisement and to make them more productive laborers." 132 Slaves and ex-slaves, on the other hand, possessed a fundamental belief in the value and power of education and literacy as a method to attain true freedom, enfranchisement, and equality. ${ }^{133}$ Pamela Barnhouse Walters charts the mechanisms used by whites to frustrate the desires of the freed slaves and their descendents. ${ }^{134}$ By first disenfranchising blacks and then set-

126. Tsesis, supra note 119 , at 124.

127. Henry Allen Bullock, A History of Negro Education in the South: From 1619 TO THE PREsent 38 (1967).

128. Id. at $38-40$.

129. Id. at 40 .

130. For example, whites who employed black servants would not allow them to work if they attended school. Id. at 43. Existing schools were also subject to mob violence. Id.

131. James D. Anderson, The Education of Blacks in the South, 1860-1935, at 8 (1988).

132. Id. at 7 .

133. Id

134. Pamela Barnhouse Walters, Educational Access and the State: Historical Continuities and Discontinuities in Racial Inequality in American Education, 74 Soc. Educ. (ExTRA ISSUE) 35 (2001). 
ting up a system of school resource allocation controlled by local officials, black children were excluded from decent education. ${ }^{135}$

The denial of education to blacks and their children was part of the method for perpetuating inequality and subordination. If states seek to overrule Plyler and deny public education to the children of undocumented workers, the denial would fit within the definition of badges and incidents of slavery. Such denial would prevent the workers and their children from becoming full members of society. It would reinforce their status as caste-members without human or workplace rights. It would prevent them from attaining the skills they need to advocate for better working conditions or enfranchisement. It would have the same effect (and could serve the same purpose) as the denial of education to slaves and freed blacks. One advantage to using this Thirteenth Amendment argument is that the state may not attempt to justify the prohibition. The Amendment clearly states that slavery shall not exist in the United States. ${ }^{136}$

Finally, the conservative approach to the Thirteenth Amendment presents alternative congressional authority to pass progressive legislation affirming Plyler. Most of our important civil rights and workers' rights legislation has been passed under congressional authority to regulate interstate commerce. ${ }^{137}$ Several commentators, however, have argued that such an approach is not analytically satisfying. ${ }^{138}$ From a practical standpoint, the Commerce Clause approach is becoming unsuccessful. Over the last twenty years, the Supreme Court has restricted the ability of Congress to pass legislation under the Commerce Clause. ${ }^{139}$ Nor should Congress rely on its plenary powers found in immigration law, for the reasons discussed above. Therefore, the broad grant of congressional authority, found in Section 2 of the Thirteenth Amendment, ${ }^{140}$ may be the best hope to pass progressive

135. Id.

136. The only exception found in the language of the Amendment is "as punishment for a crime whereof the party shall have been duly convicted." U.S. CONST. amend. XIII, $\S 1$.

137. Some legislation has been passed pursuant to the Fourteenth Amendment, but the Supreme Court has consistently found that the Fourteenth Amendment only reaches actions by state actors. Nat'l Collegiate Athletic Ass'n v. Tarkanian, 488 U.S. 179, 191 (1988). The Thirteenth Amendment, on the other hand, reaches private action. The Civil Rights Cases, 109 U.S. 3, 21-23 (1883).

138. See, e.g., James Gray Pope, The Thirteenth Amendment Versus the Commerce Clause: Labor and the Shaping of American Constitutional Law, 1921-1957, 102 CoLum. L. REv. 1 (2002); Baher Azmy, Unshackling the Thirteenth Amendment: Modern Slavery and a Reconstructed Civil Rights Agenda, 71 Fordham L. Rev. 981, 1043-44 (2002).

139. See Pope, supra note 138.

140. U.S. CONST. amend. XIII, \$ 2. 
legislation in the future. This approach also allows Congress to move away from the plenary powers doctrine as its basis for legislation in this area. Finally, since the Thirteenth Amendment reaches both private and state action, it may provide a more powerful tool for future legislative action than the Fourteenth Amendment, which only reaches state action.

\section{An Ancillary Approach: Strengthening the Fourteenth Amendment Approach Using Thirteenth Amendment Rights}

Tsesis also provides another, slightly different framework to address the issue of the educational rights of undocumented children. He suggests the potential to link the items covered by the Fourteenth Amendment's fundamental rights to the Thirteenth Amendment's badges and incidents language. ${ }^{141}$ This approach could be used in addressing the critique of Plyler's Fourteenth Amendment analysis. Although several Justices voiced the opinion that education is a fundamental right, Justice Blackmun, in his concurrence, recognized the difficulty in finding a fundamental right that cannot be linked to a specific part of the constitution. ${ }^{142}$

Tsesis argues that education, in certain circumstances, is directly implicated by the Thirteenth Amendment. ${ }^{143} \mathrm{He}$ describes a "series of parental autonomy cases regarding educational issues [which] fit in with the Thirteenth Amendment's criteria so well as to make it plausible that courts could find unconstitutional arbitrary restrictions on parental autonomy, even absent congressional action."144 These cases include Meyer $v$. Nebraska, ${ }^{145}$ where the Supreme Court struck down a state statute that prohibited schools from teaching a foreign language in elementary school, ${ }^{146}$ and Wisconsin $v$. Yoder, ${ }^{147}$ where the Court invalidated a state law requiring compulsory school attendance until the age of sixteen. ${ }^{148}$

Denial of education for undocumented children falls into this category of parental autonomy because the denial interferes with the parental rights of the undocumented adults. Interference with family

141. Tsesis, supra note 119 , at 89.

142. Plyler v. Doe, 457 U.S. 202, 231-34 (1982).

143. TSESIS, supra note 119, at 124-27.

144. Id. at 125 .

145. 262 U.S. 390 (1923).

146. II. at 402 .

147. 406 U.S. 205 (1972).

148. Id. at 234. 
autonomy and denial of parents' rights to direct and control their children were integral to slavery. ${ }^{149}$ Tsesis argues that, rather than deciding these cases on a general concept of fundamental rights unhinged from a specific constitutional protection, a Thirteenth Amendment analysis

would reflect on the institutional denial of parental autonomy in the antebellum United States and critically consider whether barring parents from particular educational or custody decisions resembles the conditions of involuntary servitude. The liberation from slavery extended to all parents the freedom to make critical decisions about their children's education. ${ }^{150}$

Thus, the argument could be made that the denial of education sometimes does implicate a fundamental right-the parental autonomy guaranteed by the Thirteenth Amendment-for Fourteenth Amendment analysis. The argument would have to be made that state prohibition on public education interferes with the parental rights of undocumented workers. Even without this explicit link, however, several Justices were willing to find in both Plyler and Rodriguez that education is a fundamental right in general. ${ }^{151}$ Other Justices were willing to find a fundamental right in Plyler, despite Rodriguez, because Plyler dealt with an absolute denial of education, and not just unequal education. ${ }^{152}$ The Thirteenth Amendment parental autonomy linkage adds another potential fundamental rights approach under the Fourteenth Amendment. Depending upon the composition of the Court, the combination of these arguments may buttress the Plyler majority's Fourteenth Amendment analysis. Unlike the Thirteenth Amendment approach, under the Fourteenth Amendment approach, States would still be able to defend this practice by showing a compelling state interest and that the prohibition was narrowly tailored to serve that interest.

This argument is parallel to, but slightly different from, the argument made in Runyon, discussed above. ${ }^{153}$ In Runyon, the Supreme

149. TSESIS, supra note 119 , at 124 .

150. Id. at 126 .

151. Plyler v. Doe, 457 U.S. 202, 230 (1982) (Justice Marshall, Justice Blackmun, and Justice Powell all offering concurring opinions); San Antonio Indep. Sch. Dist. v. Rodriguez, 411 U.S. 1, 62 (1973) (Justice Brennan, Justice White, Justice Douglas, and Justice Marshall dissenting).

152. See, for example, Justice Blackmun's concurrence in Plyler stating, "This conclusion is fully consistent with Rodriguez. The Court there reserved judgment on the constitutionality of a state system that 'occasioned an absolute denial of educational opportunities to any of its children ...." 457 U.S. at 235.

153. See supra note 113 and accompanying text. 
Court found that private schools were prohibited from discriminating on the basis of race because of a federal statute prohibiting race-based discrimination in the "making and enforcement of contracts," including contracts for educational services. ${ }^{154}$ The underlying federal statute was found constitutional-under the Thirteenth Amendmentbecause it was passed to eliminate the badges and incidents of slavery, including prohibitions on African Americans making contracts. ${ }^{155}$ In the Plyler context, the argument would be that state (not private) action is unconstitutional because it interferes with the fundamental right of parental autonomy in violation of the Fourteenth Amendment.

\section{Beyond "Badges and Incidents": Using a Holistic Thirteenth Amendment Approach for Moral Suasion and Organizing}

Although the argument can be made that the prohibition of education to the children of undocumented workers is prohibited under the conservative approaches put forth by Tsesis and Carter, there is a benefit to analyzing the issue under the broader holistic view as well. We focus on the Thirteenth Amendment as prohibiting infringements of rights at the intersection of citizenship, workers', human, and civil rights. That intersection is present because the institution of slavery, prohibited by the Thirteenth Amendment, historically involved the degradation of all of those rights.

This approach has several advantages in a litigation strategy. In terms of the involuntary servitude portion of the Thirteenth Amendment, it eliminates the difficulty of defining exactly when workers feel unable to quit a job because of coercion. In regard to the slavery portion of the Amendment, it removes the problems of determining which rights are fundamental or sufficiently linked to the history of chattel slavery. More importantly, however, the holistic approach is particularly useful as a tool of moral suasion because it places the treatment of undocumented workers and their families within the context of human rights. In addition, from an organizing perspective, it suggests a specific mechanism for bringing together several different advocacy groups.

154. Runyon v. McCrary, 427 U.S. 160, 179 (1976).

155. Id. 


\section{Moral Suasion}

The Thirteenth Amendment provides a moral language to address issues of undocumented workers and their children. By using the language of the Thirteenth Amendment, especially the holistic approach's expansive interpretation, society can begin to think about the rights of undocumented workers and their children as workers' rights, human rights, and civil rights. It gives us a way to address the issues beyond issues of sovereignty and immigration. This approach fits with the international approach to viewing a child's right to education as a right which exists at the intersection of these various important rights. Professors Connie de la Vega and David Weissbrodt state that the United Nations Committee on Economic, Social and Cultural Rights, in its General Comment 11, notes that

education can be classified as an economic right, a social right, and a cultural right, but in many ways it is also a civil and political right, since it is central to the full and effective realization of those rights as well. It epitomizes the indivisibility and interdependence of all human rights. ${ }^{156}$

A child's right to education is guaranteed in almost every important international human rights treaty. ${ }^{157}$ The Universal Declaration of Human Rights states, "Everyone has the right to education. Education shall be free, at least in the elementary and fundamental stages." 158 The International Covenant on Economic, Social and Cultural Rights, Article 13 agrees that "[t] he State Parties to the present Covenant recognize the right of everyone to education." 159 The Convention on the Rights of the Child declares, "Parties recognize the right of the child to education, and with a view to achieving this right progressively and on the basis of equal opportunity." 160 Treaties clari-

156. David Weissbrodt \& Connie de la Vega, International Human Rights Law 170 (Bert B. Lockwood, Jr., ed., 2007).

157. See Katarina Tomasevski, U.N. Special Rapporteur on the Right to Educ. and Unesco Asia \& Pac. Reg'l Bureau for Educ., Manual on Rights-Based Education: Global Human Rights Requirements Made Simple 3-5 (2004), available at http://www. hrea.org/erc/Library/display_doc.php?url=http\%3A\%2F\%2Fwww.hrea.org\%2Ferc\%2FLibrary\%2Fmanual_rightsbased.pdf\&external=n; see also C. Raj Kumar, International Human Rights Perspectives on the Fundamental Right to Education-Integration of Human Rights and Human Development in the Indian Constitution, 12 TuL. J. INT'L \& Comp. L. 237, 251-54 (2004); Human Rights Educ. Assocs., Right to Education, http://www.hrea.org/index. php?base_id=144 (last visited Feb. 5, 2008).

158. Universal Declaration of Human Rights, G.A. Res. 217A, U.N. GAOR, 3d Sess., 1st plen. mtg., U.N. Doc A/810 (Dec. 12, 1948).

159. International Covenant on Economic, Social and Cultural Rights, Dec. 16, 1966, 993 U.N.T.S. 3.

160. Convention on the Rights of the Child, Nov. 20, 1989, 1577 U.N.T.S. 3. 
fying that countries may not discriminate in the provision of education are found in the International Convention on the Elimination of All Forms of Racial Discrimination ${ }^{161}$ and The International Convention on the Protection of the Rights of All Migrant Workers and Their Families. ${ }^{162}$ That latter Convention assures that "each child of a migrant worker shall have the basic right of access to education on the basis of equality of treatment with nationals" and prohibits lack of access due to the "irregular situation" of a child or parent. ${ }^{163}$ Indeed, these treaty obligations provide another basis, on grounds that parallel the holistic approach of the Thirteenth Amendment, to recognize a federal duty to ensure the children of undocumented workers access to basic education. ${ }^{164}$

\section{Organizing}

From an organizing standpoint, conceiving the education issue in broad Thirteenth Amendment terms provides a concrete connection to advocacy groups focusing on labor rights, human rights, and civil rights. Recognizing the linkages between the various groups currently representing workers' rights (traditionally organized labor), citizenship rights (immigrant rights groups), human rights (those working with enslaved or trafficked workers), and civil rights (groups addressing the systemic deprivation of rights caused by membership in a racial or ethnic minority) enhances social mobilization and organization. ${ }^{165}$ Significant strides have already been made in uniting labor and immigrant rights groups to fight abusive governmental action taken by the government against immigrant workers. ${ }^{166}$ That effort has included lawsuits filed by labor unions seeking to protect the constitutional rights of documented and undocumented workers, arising out of workplace immigration raids that had particularly detri-

161. Article 5 requires that state parties agree to principles of nondiscrimination in the enjoyment of the right to education. International Convention on the Elimination of All Forms of Racial Discrimination, Dec. 21, 1965, 660 U.N.T.S. 195.

162. International Convention on the Protection of the Rights of All Migrant Workers and Members of Their Families, Dec. 18, 1990, 2220 U.N.T.S. 3.

163. Id.

164. For an interesting article that uses these treaty provisions as an enforcement model and surveys the possibility of a federal right to education, see Kimberly Jenkins Robinson, The Case for a Collaborative Enforcement Model for a Federal Right to Education, 40 U.C. Davis L. REv. 1653 (2007).

165. For more on social mobilization and organizational implications of the holistic vision of the Thirteenth Amendment, see Maria L. Ontiveros, Immigrant Rights and the Thirteenth Amendment, 16 NEw L.AB. Forum 26 (2007).

166. Maria L. Ontiveros, Out of the Shadows and into the Spotlight: Immigrants and Organized Labor, 11 WORKINGUSA 157 (2008). 
mental effects on the families of the workers. ${ }^{167}$ The education issue provides an opportunity to emphasize the connection between organized labor, immigrant rights groups, and those groups concerned with human rights and civil rights. A holistic Thirteenth Amendment approach provides a common language for these various groups because it illustrates how the denial of education was central to the denial of civil and human rights of slaves and shows how it threatens the civil and human rights of immigrant workers today.

\section{Conclusion}

Plyler remains a vital piece of Supreme Court jurisprudence ensuring that no segment of our society is relegated to an inferior class. Presently, no child may be denied that basic means by which we all participate in society and by which we all better ourselves, our families, and our communities.

As this Article demonstrates, there are reasons to remain cautious. There have been legislative attempts to undo Plyler, as well as opposition at the most local levels. Further, the Supreme Court is not immovable.

This Article presents the Thirteenth Amendment as a potential buttress to those who believe the Constitution guarantees undocumented children the right to an education. It demonstrates the viability of a Thirteenth Amendment argument under a conservative framework, and argues that a broader vision of the Amendment more accurately reflects its true nature while offering strategic advantages in litigation. This Article also suggests that recognizing the Thirteenth Amendment's position at the intersection of citizenship, workers', human, and civil rights creates a tool for moral suasion and advocacy organizing.

The Supreme Court's decision in Plyler recognized that a blunt assertion of immigration policies should not render the Constitution irrelevant to a broad segment of our established populace. Indeed, when put in these straightforward terms, when viewed through a wide lens, the outcome is clear. In this situation, the relevant constitutional provisions include both the Thirteenth and Fourteenth Amendments. While some fail to recognize that the conditions one would consider indicative of slavery have continued to emerge since the abolition of chattel slavery, this Article seeks to awaken advocates to those realities by recognizing the Thirteenth Amendment's current relevance. Such

167. Id. 
awareness can encourage a wider dialogue in society generally. As people realize the Amendment is not limited to the prohibition of chattel slavery, they can begin to see how denying their neighbor's child access to education reflects the type of iniquity they thought relegated to the pages of history. 
